\title{
Studies on physico-chemical properties of multi-flour noodles during storage
}

Sunil, Neelesh Chauhan, Vipul Chaudhary, Vikrant Kumar and Ratnesh Kumar

Received : 17.01.2019; Revised : 16.02.2019; Accepted : 07.03.2019

See end of the Paper for authors' affiliation

Correspondence to :

Sunil

Department of Agricultural Engineering, Sardar Vallabh

Bhai Patel University of Agriculture and Technology, Modipuram Meerut (U.P.)

India

Email : sunilchandelnduat6771

@gmail.com
- ABSTRACT : Experiments were conducted to development, quality evaluation and storage stability of multi- flour noodles made from wheat flour, soya bean flour, carrot powder, mushroom flour and apple pomace powder. The noodles were formulated by taking different proportion of multi-flours in the ratio of $\left(\mathrm{T}_{100}\right)$ 100:0:0:0:0, $\left(\mathrm{T}_{90}\right)$ 90:2.5:2.5:2.5:2.5, $\left(\mathrm{T}_{80}\right)$ 80:5.0:5.0:5.0:5.0, $\left(\mathrm{T}_{70}\right)$ 70:7.5:7.5:7.5:7.5, $\left(\mathrm{T}_{60}\right)$ 60:10:10:10:10 and $\left(\mathrm{T}_{50}\right)$ 50:12.5:12.5:12.5:12.5 respectively. Wheat flour of the ratio of 100:0:0:0:0 was considered as control. All the samples were packed in high density polyethylene (HDPE) and stored at room temperature from 0 to 60 days for quality evaluation. After preparation of noodles various physico-chemical properties were determined, i.e., moisture content, ash content, protein content and fat content.

- KEY WORDS : Multi- flour, Noodles, High density polyethylene

-HOW TO CITE THIS PAPER : Sunil, Chauhan, Neelesh, Chaudhary, Vipul, Kumar, Vikrant and Kumar, Ratnesh (2019). Studies on physico-chemical properties of multi-flour noodles during storage. Internat. J. Agric. Engg., 12(1) : 96-100, DOI: 10.15740/HAS/IJAE/12.1/96-100. Copyright @2019: Hind Agri-Horticultural Society. 